\title{
Resenha: "Mas Ele Diz que me Ama...": Cegueira Relacional e Violência Conjugal
}

\author{
Fabrício Guimarães \\ Eduardo Chaves da Silva \\ Universidade de Brasília \\ Psicossocial Forense \\ Sérgio Alberto Bitencourt Maciel ${ }^{1}$ \\ Núcleo Psicossocial Forense
}

\section{Book Review: “But He says He Loves me...”: Relational Blindness and Conjugal Violence}

\section{Ciclo de Violência na Relação}

O padrão é mais ou menos esse: beijo! Tapa! Beijo! Tapa! Beijo! Tapa! Para cada tapa, ganhamos um beijo, e para cada beijo ganhamos um tapa. Em qual deles escolhemos acreditar? No beijo, é claro. É o que nos mantém ali (Penfold, 2006, p. viii-ix).

Pelfond (2006) relata em sua obra a suas experiências conjugais que se perpassaram ao longo de 10 anos. O livro é protagonizado por Rosalind (Ros) - 35 anos, empresária - e Brian - viúvo, pai de quatro filhos. A narrativa mostra como Ros passou de uma mulher forte e bem-sucedida a esposa violentada e maltratada. Trata-se de um livro ilustrado e de fácil compreensão, fatores diferenciais da obra em relação às outras sobre o tema. Conta de forma bem didática, detalhes da construção e manutenção da dinâmica violenta. Segundo o site oficial (www.friends-of-rosalind.com), o livro foi lançado originalmente no Canadá e traduzido para 10 paises, inclusive o Brasil.

O objetivo deste trabalho situa-se em promover uma discussão teórica a respeito do ciclo de violência conjugal e das crenças compartilhadas que contribuem para a manutenção do relacionamento violento dos personagens do livro, a partir da literatura especializada da área e da experiência dos autores deste trabalho em atendimentos psicossociais no âmbito da Justiça do Distrito Federal a casais que vivenciam situação semelhante ao do casal protagonista.

A discussão se baseia na teoria do ciclo de violência (Walker, 1979, citada por Angelim, 2004), e propõe o conhecimento de uma relação violenta a partir de uma perspectiva sistêmica e dinâmica. Walker defende a existência de três fases: Construção da Tensão: começam os incidentes menores, uma tendência a considerar os fatos como se estivessem sob controle e uma aceitação por meio de explicações racionalizadas. Tensão Máxima: ocorre o descontrole da situação e as agressões são levadas ao extremo. Há uma reconfiguração da

1 Endereço: Núcleo Psicossocial Forense, SRTVS, Quadra 701, Bloco N, Lote 08, $4^{\circ}$ andar, Brasília, DF, Brasil 70.40-903. E-mail: sergio. maciel@tjdf.gov.br dinâmica relacional, podendo surgir separação, intervenção de terceiros ou manutenção da relação violenta. Lua de Mel: ocorre uma reestruturação do relacionamento. $\mathrm{O}$ agressor relata desejo de mudança, promessa de que não ocorrerá mais violência e restabelece a relação conjugal. Com o tempo, devido à dinâmica e ao desgaste relacional, tende-se a iniciar um novo ciclo.

Penfold (2006) descreve o processo de vários ciclos na dinâmica do casal. A violência se instalou sutilmente e atingiu todos os níveis e formas. Os momentos da fase de Lua de Mel ficaram mais curtos, cedendo lugar às fases de Construção da Tensão e Violência Máxima. A Lei 11.340/06, conhecida como "Lei Maria da Penha", define cinco formas principais de violência contra a mulher: física; psicológica, sexual, patrimonial e moral (Brasil, 2006). Guimarães, Tusi e Rangel (2006) relatam que a violência contra crianças e adolescentes abrange ameaças, negligência, chantagens, humilhações, espancamentos e abuso sexual. A relação descrita na obra propiciou todos esses tipos de violência e mostrou como suas conseqüências deletérias atingiram todos os aspectos da vida de Ros e das crianças.

Penfold (2006) é brilhante ao mostrar como a participação da família, amigos e ajuda profissional foram fundamentais na luta da protagonista contra o agressor e, de certa forma, contra si mesma. Sendo assim, tudo conclama para a necessidade de intervenção em rede e o empoderamento do grupo familiar, em especial da mulher (Silva, 2006).

\section{Crenças anestésicas}

Por que Brian se comportava daquele jeito? Quase morri tentando descobrir. Por que não fui embora? Essa pergunta é mais importante. Eu acreditava em dar a outra face... que ele me amava... que ele iria mudar.. que eu podia proteger seus filhos... que meu amor o tornaria melhor... usei incontáveis desculpas para racionalizar minha insistência no relacionamento, porque me recusava a encarar a verdade (Penfold, 2006, p. ix).

Para entender a perpetuação do ciclo de violência, Ravazzola (1998) defende que ocorre uma verdadeira anestesia ou "duplo cego". Nesse processo, a pessoa tira do seu campo de consciência uma parte da experiência e fica incapaz de sequer perceber essa falta, o que, por um lado assegura 


\section{F. Guimarães e cols}

sua sobrevivência, mas por outro, a mantém presa ao ciclo relacional abusivo.

$\mathrm{O}$ agressor se sente vítima do comportamento da mulher ou dos filhos; teme a independência destes; não percebe o sentimento dos outros e nem consegue nomear sua insegurança, e por isso tem que controlar a ação destes e evitar a intervenção de terceiros na dinâmica de sua família. A vítima se sente inferior e destituída de poder sobre sua própria vida; acredita que deve cuidar dos outros, em detrimento de si mesma; possui baixa auto-estima, desconhecimento de seus recursos pessoais e seus direitos; acredita que há algo errado em si mesma e alimenta sentimento de culpa pela violência que sofre. Cabe ressaltar que a experiência em atendimento psicossocial dos autores corrobora a tese de que tais crenças são compartilhadas por agressores, vítimas e demais atores do contexto (Ravazzola, 1998).

No decorrer do livro, essas crenças anestésicas se aperfeiçoam na medida em que a violência aumenta. Ros iniciou com uma leve confusão no primeiro ciclo até ela verificar que "não sobrou nada de mim" (Penfold, 2006, p.169). Essas crenças corroboram a principal: "mas ele diz que me ama", que dá título ao livro. E favorecem que Ros e Brian não vejam que não vêem a relação violenta e suas conseqüências, daí o termo "duplo cego" (Ravazzola, 1998).

Por isso, a ajuda de terceiros e/ou a intervenção psicossocial deve "promover junto à família uma reflexão sobre o contexto abusivo, re-significando o sintoma da violência" (Guimarães \& cols. 2006, p. 297) e retomar o mal-estar e o medo na vítima devido à sua situação e a necessidade de mudança (Ravazzola, 1998). Entretanto, nem todos os casais em situação de violência conseguem sair ou reestruturar a relação. Muitos precisam da intervenção da Justiça. Em outros casos, as mulheres se submetem a essa situação $a d$ infinitum ou ocorre um fim trágico, em que as vítimas são assassinadas pelos seus cônjuges ou ex-cônjuges.

comecei a ter esperanças de que meus desenhos pudessem ajudar os outros - nem que seja uma pessoa só-a perceber os danos terriveis e duradouros que tal ambiente causa em uma família (...) embora os desenhos sejam meus, infelizmente o padrão de abuso que eles representam são muito comuns (...) Tenho esperanças de que meus desenhos ajudem homens $e$ mulheres a identificar os sinais de alerta que indicam abuso (Penfold, 2006, p. xi).
Pelos aspectos descritos acima, entende-se que a intervenção junto a casais em situações de violência deve contemplar um olhar amplo acerca das crenças e discursos compartilhados entre os atores envolvidos nessa questão, os quais contribuem para a manutenção do padrão relacional abusivo, impedindo que as pessoas integrem sentimentos e ações que lhes permitam elaborar um pedido ajuda.

Ademais, o entendimento da violência conjugal como um processo cíclico, relacional e progressivo, ajuda a resignificar o contexto de intervenção e propor novas formas de intervenção junto a essa clientela.

\section{Referências}

Angelim, F. P. (2004) Construindo novos discursos sobre a violência doméstica: uma articulação entre a Psicologia Clínica e a Justiça. Dissertação de Mestrado, Universidade de Brasília, Brasília.

Brasil (2006). Lei 11.340 de 07/08/2006 - "Lei Maria da Penha”. Retirado em 28/03/2007 do http://www.planalto.gov.br/ ccivil/_Ato2004-2006/2006/Lei/L11340.htm

Guimarães, F., Tusi, M. M. A. \& Rangel, R. B. (2006). Intervenção Psicossocial em casos de Abuso Sexual na Justiça: Proposta Metodológica. Em E. C. B. Roque, M. L. R. Moura \& I. Ghesti (Orgs.), Novos Paradigmas na Justiça Criminal: Relatos de Experiências do Núcleo Psicossocial Forense do TJDFT. Brasília: TJDFT.

Penfold, R. B. (2006). Mas ele diz que me ama. Graphic novel de uma relação violenta. (D. Pelizzari, trad.). Rio de Janeiro: Ediouro. (Trabalho original publicado em 2005)

Ravazzola, M. C. (1997). "Doble Ciego" o "No Vemos que No Vemos”. Em M. C. Ravazzola (Org.), Histórias Infames: los Maltratos en las Relaciones (pp. 89-105). Buenos Aires: Ed. Paidos.

Silva, E. C. (2006). O agressor sexual de crianças no contexto sócio-jurídico. Monografia de Conclusão do Curso de Serviço Social, Universidade de Brasília, Brasília.

Recebido em 20.04.2007

Primeira decisão editorial em 28.06.2007

Versão final em 13.08.2007

Aceito em 08.10.2007 